Vol. 28, No. 1, June 2021

P-ISSN: 0854-8919, E-ISSN: 2503-1023

Nationally Accredited Journal, Decree MoHE No. 148/M/KPT/2020.

\title{
ASEAN Non-Intervention Principles: An Alternative Settlement towards Human Rights Violation in Rohingya
}

\author{
Yulianto Achmad*, Nanik Prasetyoningsih, M. Reformis Al Fath \\ Faculty of Law, Universitas Muhammadiyah Yogyakarta \\ ${ }^{*}$ Corresponding author: yuliantoachmad@umy.ac.id
}

\begin{tabular}{l} 
ARTICLE INFO \\
\hline Keywords: \\
human rights violations; \\
Non-Intervention \\
Principle; Rohingya ethnic \\
How to cite: \\
Achmad, Y., \\
Prasetyoningsih, N. \& \\
Al Fathh, M.R. (2021). \\
ASEAN Non- \\
Intervention Principles: \\
An Alternative \\
Settlement towards \\
Human Rights Violation \\
in Rohingya. Jurnal \\
Media Hukum, 28(1), 118- \\
135. \\
Article History: \\
Received: 18-01-2021 \\
Reviewed: 12-03-2021 \\
Revised: 2812-04-2021 \\
Accepted: 30-06-2021 \\
\end{tabular}

\begin{abstract}
The frame of international news is colored with a series of systemic and consistent human rights violation experienced by the Rohingya ethnic group in Burma. Toward this case, it is unlikely for Burma to be willing and to be able to resolve this case internally. Hence, as a regional security and stability guard in the Southeast Asia region, ASEAN should take part in settling human rights violations that occur in its member states. However, every settlement attempted by ASEAN is constantly distracted with Non-Intervention Principles. This research aims to examine the alternative ideas for NonIntervention Principles of ASEAN as a settlement towards human rights violation on Rohingya ethnic. This research used normative research, based on the secondary data was employed as the research method. The obtained data were analyzed by using qualitative analysis. The research found that the Non-Intervention principle has been applied in ASEAN in the most rigid form. Meanwhile, Humanitarian Assistance and Humanitarian Intervention mechanism is an alternative settlement towards human rights violations on the Rohingya ethnic group in Myanmar.
\end{abstract}

DOI: https://doi.org/10.18196/jmh.v28i1.10892

Copyright (C) 2021 JURNAL MEDIA HUKUM. All rights reserved.

\section{Introduction}

News about the tragedy of human rights violations (hereinafter abbreviated to HR) in the form of expulsion, violence, rape, and killings experienced by the Rohingya ethnic minority in Myanmar decorated the international news frame in 2012. A similar incident also surfaced back in 2017 with the same victim. This crime disturbs the conscience of anyone who sees it because this tragedy is, in fact, the tip of the iceberg on a series of precedents of human rights violations that befall the Rohingya ethnic group. The first recorded incident was in 1942, known as the Arakan Massacres 1942, where the Rohingya were killed so that the total death toll was estimated to more than 
$40,000 .{ }^{1}$ Due to the consistent human rights violations that have befallen them, most of the Rohingya ethnic groups choose to leave their homeland to migrate through land and sea routes to seek asylum to neighboring countries such as Bangladesh, Malaysia, Thailand, and even Indonesia. To make matters worse, the crisis has not subsided and has increased dramatically in 2012. It is estimated that around 120,000 Rohingyas have traveled across the Andaman Sea. ${ }^{2}$

Myanmar is one of the members of the Association of Southeast Asian Nations (hereinafter abbreviated to ASEAN), the regional organization of the Southeast Asia region established on August 8, 1967, in Bangkok. ASEAN is a forum that is concerned about economic, cultural cooperation, and the protection of human rights. In the case of human rights violations against the Rohingya ethnicity within the jurisdiction of Myanmar, ASEAN should take constructive steps to assist efforts to resolve human rights violations that occurred in Myanmar. Due to the fact that Myanmar is unlikely to resolve these human rights violations internally. Destructive action by Myanmar such as the abolishment of Rohingyas citizenship by Pyithu Hluttaw Law 1982 (Burma Citizenship Law 1982), disobedience toward United Nations Resolutions, and rejection of all dialogue solutions in the ASEAN forum are adequate to show that Myanmar is unlikely to resolve these human rights violations.

As a regional organization, ASEAN has been equipped with a set of norms to order the relationship between its member states. One of the various norms is the NonIntervention Principles which were adopted from the Universal Declaration of Human Rights by the United Nations. In simple terms, this principle contains the prohibition against interfering in the internal affairs of other member countries. The existence of the Non-Intervention Principle is found in several ASEAN legal documents and instruments. Lots of documents containing this principle resulted from the limited role of ASEAN and member countries to play more roles in regional dynamics in Southeast Asia. $^{3}$

In the scope of ASEAN membership, the settlement of this case has been attempted at the ASEAN Intergovernmental Commission on Human Rights (AICHR) meetings in 2013 and 2014, which has always failed to produce policies towards Myanmar. As an institution, ASEAN is not ready yet to respond to this case because of the adoption of the Principles of Non-Intervention from the United Nations Declaration of Human Rights, whose implementation depends on the socio-cultural context of the country concerned. In this case, Southeast Asia is accustomed to using a discussion approached and soft diplomacy. The approach taken by ASEAN in various meetings has always been countered by Myanmar on the pretext that the Rohingya case is an internal state affair and violates the Non-Intervention Principle. ${ }^{4}$

${ }^{1}$ Mohajan, H. (2018). The Rohingya Muslims in Myanmar are Victim of Genocide. ABC Journal of Advanced Research, 7(1), p. 9

2 Jati, I. (2017). Comparative Study of the Roles of ASEAN and the Organization of Islamic Cociteration in Responding to the Rohingya Crisis, the Indonesian Journal of Southeast Asian Studies. 1(1), p. 17

${ }^{3}$ Rahmanto, T.Y. (2017). Prinsip Non-Intervensi bagi Asean ditinjau dari Perspektif Hak Asasi Manusia. Jurnal HAM, 8(2), p.150

${ }^{4}$ Salim, T. (2016). No ASEAN Meeting to Discuss Rohingya. [Accessed on March 27, 2021]. Available at, https://www.thejakartapost.com/news/2016/11/26/no-asean-meeting-todiscuss-rohingya.html. 
The non-intervention principle in ASEAN is interpreted as the most rigid condition in which this condition is no longer relevant to the development of the constellation of international relations, especially if what happens is a phenomenon of systemic humanitarian violations that have occurred in a country. Therefore, the NonIntervention Principles of ASEAN as an alternative settlement towards human rights violations on Rohingya ethnic groups is an idea that needs to be discussed. The research focused on the following question: What is the need for alternatives of NonIntervention Principles of ASEAN as settlement towards human rights violations on Rohingya ethnic group?

\section{Method}

This type of this research is normative research, whose object of study includes legal rules or regulations. This type of research puts the law as a norm system building related to a legal event. Whereas in this study, the authors used the statute approach, conceptual approach, and case approach. Sources of data used in this study are secondary data, namely data obtained from reviewing literature or various literature related to problems in research which are then called legal materials. The primary legal materials include regulations and international conventions related to this research. Meanwhile, secondary legal materials include books, related journals, seminar papers, articles by legal circles or agencies, answers from interviewees, as well as other written sources, both printed and electronic. Data is collected through (library research) on legal materials, and the data obtained will be analyzed using qualitative analysis methods

\section{Results and Discussions}

\subsection{Non-Intervention Principle in the Concept of State Sovereignty Theory}

The word "Sovereignty" is a translation of Sovereignty in English. Meanwhile, in French, it is called Souverainete, and derived from "Supereanus" which means the highest. ${ }^{5}$ From the historical perspective, the emergence of this concept of sovereignty originated before the 16th century when the Uthmaniyyah Daula expanded the territory of its caliphate to mainland Europe. European countries remained in a state of disunity so that they were easily conquered by Islamic forces. Until the 16th century, the Church took the initiative to form an alliance between European countries on the basis of religious equality to fight the power of the Islamic State. In short, there was a large meeting in 1648, known as the Westphalia Conference. At this conference, a document called the Treaty of Westphalia was produced. The contents of the agreement recognize the principles of state sovereignty, territorial integrity, and state equality. ${ }^{6}$ The Westphalia Agreement, later became the embryo of international law and was embedded in the non-intervention principle.

When discussing the concept of sovereignty, the central issue that arises is who is the owner as well as the source of sovereignty. Another similar question is who the authority has the right to hold sovereignty in a country.

\footnotetext{
${ }^{5}$ Kusumaatmadja, M \& Agoes, E.R. (2003). Pengantar Hukum Internasional, Bandung: Penerbit Alumni, p.16

6 Islami, M.N. (2017). Hukum Internasional dalam Perspektif Islam dan Kedaulatan Bangsa. Yogyakarta: Pustaka Pelajar, p.15-16
} 
Meanwhile, Ibn Taimiyyah ${ }^{7}$ viewed that leading the ummat is an obligation, and religion cannot stand firm without a leader. Also, Allah has obliged the Muslims to perform good deeds and forbid every munkar, and the leader can overview those deeds. Thus, a leader who holds sovereignty is elected based on deliberation (such as in the days of Khulafaur Rasyidin) as the "representative of God" and burdened with the obligation to carry out his leadership according to the Al-Qur'an, As-Sunnah, and ijtihad. As a result, sovereignty is fully subjected to and referred to in Allah's Law.

In contrast to the concept of sovereignty according to Western understanding, after studying, it turns out that there is a contradiction between state sovereignty and the enforcement of international law. A 16th-century French scholar named Jean Bodin then formulated a scientific form of this theory of sovereignty. According to him, the element of sovereignty contains the only power as: ${ }^{8}$

1. Original, it is not reduced to another power;

2. The highest, that there is no other power whose position is higher so that it can limit its power;

3. Eternal;

4. It cannot be shared and transferred to another institution/agency.

Meanwhile, according to J.J. Rousseau, the concept of sovereignty is populist and based on the will of the general public (volente generale). He believed that people should incarnate through legislation. Therefore, the concept of sovereignty has four characteristics: ${ }^{9}$

1. Unity;

2. Sovereign, undivided (indivisibilite);

3. Cannot be transferred (inatienabilite);

4. Constant (imprescriptibilite).

Furthermore, to create sovereignty, of course, there must be an area to practice its sovereignty. This controlled territory is called jurisdiction. Scientifically, jurisdiction means the power of the state under international law to regulate individuals and the material within it. Hence, if the state is able to control its territory based on its national legal system effectively, it has jurisdiction. ${ }^{10}$

Jurisdiction at the level of international law is very substantial because, according to the territorial principle, every country has jurisdiction over crimes committed within its territory. A country must have jurisdiction over every person, object, and various criminal and civil cases within its territorial boundaries as a sign of a sovereign country. ${ }^{11}$

The above phenomena show that the country's sovereignty should be placed highest in the norm system. As times have evolved, this paradigm has become a contradiction with the enforcement of international law, which regulates the pattern of relations

\footnotetext{
${ }^{7}$ Ibnu Taimiyah. Al-Siyasah al-Syari'ah, p. 172-173

8 Islami, M.N. Op.Cit., p.77-78

${ }_{9}^{9}$ Djauhari. (2005). Kedaulatan Rakyat dalam Perspektif Islam. Jurnal Hukum, 15(2), p. 211

${ }^{10}$ Irawan, J. (2018). Pelaksanaan Yurisdiksi Universal. Yogyakarta: Rajawali Press, p. 9-10

11 Adolf, H. (1996). Aspek-Aspek Negara dalam Hukum Internasional. Jakarta: Raja Grafindo Persada., p. 145
} 
between international legal subjects. Then the sovereignty becomes subject to international law, or the sovereignty is superior to international law.

There are two concepts to answer this problem. First, the concept of Absolute Sovereignty places the state with all the characteristics of absolute sovereignty and cannot be limited by other supreme powers. When linked to the definition, according to the previously stated description, this concept considers that a state is not subject to international law or any provisions from outside the country. Sovereignty also occupies the top strata in the hierarchy of the normative legal order, which has an impact on the position of international law under national law. In addition, the sovereignty of a country is the mandate of the people to organize a government instead of a delegation of international law. ${ }^{12}$ This concept is identical to the Westphalia Agreement of 1648, characterized by a rigid application of the classic non-intervention principle.

Second, the concept of relative sovereignty considers sovereignty to have limitations that cannot overstep international law. One of the scholars who support this concept is Mochtar Kusumaatmadja. He argues that the highest power is limited by the boundaries of the country's territory or territory and that power ends where another country's power started. So, according to this concept, sovereignty (which is attached to the principle of non-intervention) must not conflict with international law or, in other words, be subject to international law. ${ }^{13}$ Thus, this concept is more suitable for the current conditions.

\subsection{The Implementation of Non-Intervention Principles in ASEAN Perspective}

ASEAN was born in the midst of a world that was experiencing the turmoil of the Cold War. One of the salient features of this war was the occurrence of ideological contestation on the stage of global hegemony, the Western Block, with its liberalcapitalism ideology, and the Eastern Block, with its Communist ideology. Southeast Asia at that time was filled with newly independent countries, and because of the common goal of avoiding the hegemony of these ideologies, several countries (Indonesia, Malaysia, Thailand, Philippines, Singapore) then attempted to form a regional organization in Southeast Asia. The formation of ASEAN was through a long process, and the founding countries experienced a steep path to the dynamic of organizational life. It was started with the establishment of the Association of Southeast Asia (ASA), followed by Maphilindo, but those two were later dismissed. ${ }^{14}$

The understanding of the Non-Intervention Principles, which was born from the Westphalia 1648 agreement, was adopted and adhered to by ASEAN members. Although in various official ASEAN documents, the definitive definition of the nonintervention principle is not stated explicitly. One of the international legal experts named John Funston gave an understanding of the non-intervention principles in ASEAN, that "Some of the forms of non-interference include that governments must refrain from making any comments on the internal state issues of another member state, even to the extent of airing sensitive documentaries or news reports of other

\footnotetext{
12Ibid., p.183

13 Kusumaatmadja, M, Loc.Cit.

14 Burmansyah, E. (2014). Rezim Baru ASEAN: Memahami Rantai Pasokan dan Masyarakat Ekonomi ASEAN. Yogyakarta: Pustaka Sempu, p.29
} 
member states."15 In his statement, Funston stated that the definition of nonintervention adopted by ASEAN is any form of intervention that requires each country not to comment at all on internal issues that are happening in other member countries.

Historical, socio-cultural, and economic similarities between ASEAN member states have initiated the non-intervention principle into the ASEAN legal instruments. The 1967 ASEAN Declaration is a momentum of the birth of ASEAN, which contains the aims and objectives of the establishment of this organization. In terms of relations between member countries, ASEAN uses the Non-Intervention principle as set out in the fifth paragraph of this declaration as a substantial principle that member states must adhere to:

"CONSIDERING that the countries of South-East Asia share a primary responsibility for strengthening the economic and social stability of the region and ensuring their peaceful and progressive national development and that they are determined to ensure their stability and security from external interference in any form or manifestation in order to preserve their national identities in accordance with the ideals and aspirations of their peoples." 16

Realizing the development of the international political constellation, ASEAN member countries have begun to seriously understand to be able to build a sense of security, peace, prosperity, and regional political stability. So that ASEAN chooses a neutral position in the arena of international politics. On these grounds, the ZOPFAN Declaration, which stands for Zone of Peace, Freedom, and Neutrality, was prepared in 1971. The use of the Principle of Non-Intervention is very substantial in this ZOPFAN Declaration because it is mentioned five times spread over several paragraphs. Five years after the signing of the ZOPFAN Declaration, the first Summit was held in Bali in 1976 and established the ASEAN Concord Declaration as a set of rules governing cooperation in the political, economic, socio-cultural, and security sectors. The principle of non-intervention appears again in this declaration in the eighth part of the Do Hereby Declare point. ${ }^{17}$

The existence of the principle of non-intervention was only formulated in standard form on February 24, 1976, in a treaty called the Treaty of Amity and Cooperation (TAC). TAC is an ASEAN regional legal framework designed to become normative rules that have been institutionalized into binding obligations under an agreement. ${ }^{18}$ This treaty was formed with the aim of promoting regional peace and stability, in which there are principles that serve as a guideline for parties accessing it. The fundamental principles (one of which is the Non-Intervention Principles) are regulated in the TAC in Article 2:

"In their relations with one another, the High Contracting Parties shall be guided by the following fundamental principles:

a. Mutual respect for the independence, sovereignty, equality, territorial integrity, and national identity of all nations;

${ }^{15}$ Linjun, W.U. (2000). East Asia and the Principle of Non-Intervention: Policies and Practices. Maryland Series in Contemporary Asian Studies, 5(160), p. 1

${ }^{16}$ ASEAN Declaration 1967

17 Media Amora. (2010). Arti Strategis Piagam Asean (Asean Charter) terhadap Kerjasama Regional Asean. (Tesis). Universitas Indonesia, Indonesia, p.1-2

18 Donald E. Weatherbee. (2009). International Relation in Southeast Asia: The Struggle for Autonomy. USA: Rowman \& Littlefield Publishing Group, p. 129-130 
b. The right of every State to lead its national existence free from external interference, subversion, or coercion;

c. Non-interference in the internal affairs of one another;

d. Settlement of differences or disputes by peaceful means;

e. Renunciation of the threat or use of force;

f. Effective cooperation among themselves."19

On December 15, 2008, at the ASEAN secretariat Jakarta, the ASEAN Charter was legally binding after being ratified by all member countries. With the stipulation of the ASEAN Charter as the basic statute of the organization, it is expected to strengthen ASEAN with legal personality. Legal personality provides authority to act guaranteed by international law. ${ }^{20}$ The birth of the ASEAN Charter also confirms its position as a legal personality in international law through its Article 3. Furthermore, the regulation of the principles adopted by ASEAN, including the principle of non-intervention, can be found in Article 2 paragraph (2) of the ASEAN Charter.

The use of the Non-Intervention Principle in various ASEAN legal instruments and documents indicates the existence of this principle in the constellation of organizational life in ASEAN. For ASEAN, the application of the principle of non-intervention is always seen in accordance with the spirit of nation-building, which was proclaimed by the Founding Fathers and ASEAN itself as its goal from the start. The application of the Principles of Non-Intervention in ASEAN can be said to be in the most rigid form and cannot at all be equated in its implementation with the practice of the United Nations.

\subsection{Human Rights Violations Toward Myanmar's Rohingya Ethnic}

Burma is the old term for the current state of Myanmar. Burma or Birma is taken from the name of the Union of Burma Socialist Republic (Dyadaungan Socialist Thammada Myanma Nainnggnan). The Burmese State gained sovereignty in 1948. On June 18, 1989, the Military Junta at that time changed the name Burma to Myanmar. The capital was also changed its name from Rangoon to Yangon until, on November 7, 2005, the capital of Myanmar was moved to Naypyidaw. ${ }^{21}$ The name change to Myanmar is intended as a form of government protection for minority groups living in the country because Burma is one of the names of the largest ethnic groups in Myanmar.22

Myanmar is a multi-ethnic country consisting of hundreds of different tribes and ethnicities. Demographically, Myanmar has a population of approximately 51 million people, with nearly $30 \%$ living in urban areas. The country has 135 recognized ethnic groups making it a multi-ethnic country. The largest ethnic group in Myanmar is the Burmese, which makes up two-thirds of the total population.

The Rohingya are an ethnic minority who are Muslim and live in the state of Rakhine (formerly Arakan). Islam itself developed in Myanmar beginning in the 9th century,

19 Treaty of Amity and Cooperation 1976

${ }^{20}$ Malcolm N. Shaw in Husni Thamrin. (2018). Rohingya-Myanmar Crisis: How is ASEAN Intergovernmental Commission on Human Rights?. International Affairs and Global Strategy, 63(1), p.24

${ }^{21}$ Saifullah. (2010). Sejarah dan Kebudayaan Islam di Asia Tenggara. Yogyakarta: Penerbit Pustaka Pelajar, p. 186

22 Gunawan, Y \& Priambodo, G. (2013). Burma's Rohingya Case in International Law

Perspective. Jurnal Media Hukum, 20(1), h. 161 
and an Islamic state was recorded in Arakan in the 14th century by King Sulayman Naramitha, who was assisted by the Sultan of Bengal, Naseerudden Mahmud Syah. ${ }^{23}$ There are two opinions regarding the origin of the Rohingya ethnicity. The first opinion says that the Rohingya are an indigenous Arakan tribe. The second opinion states that the Rohingya are immigrants from Bangladesh, considering that northern Rakhine is indeed a land border with Bangladesh. However, from these two opinions, all agree that the Rohingya have lived in Arakan for hundreds of years. ${ }^{24}$

According to the history of the Government of Myanmar (GoM) version, during the British colonial period, there was a massive migration of people from India and Bangladesh to Myanmar territory. They (Rohingya) come to Myanmar during the harvest season and work as laborers. During World War II, ethnic Burmese people sided with Japan, while minority ethnic groups (Karen, Kachin, Rohingya) sided with the British. When Britain lost the war in 1942, ethnic minorities, including the Rohingya, fled to Bangladesh. ${ }^{25}$

On the basis of the socio-historical experience of the Rohingya people who are viewed with sentiment and negatively by the Myanmar people, coupled with the physiological similarity between the Rohingya and the Bangladeshis, the Rohingya are considered not part of Myanmar and often receive repressive actions from local residents, Buddhist leaders, and elements of the apparatus. Ultimately, these human rights violations seemed to be legalized by the Myanmar government with the issuance of the Pyithu Hluttaw Law 1982 or Burma Citizenship Law 1982, which stated that only 135 races listed in the Law were entitled to full citizenship status. As for the Rohingya ethnicity not listed on the list, this has resulted in the Rohingya being stateless. ${ }^{26}$

Compiled from the report of the UN Special Rapporteur, who is the UN envoy to report on the condition of human rights in certain countries ${ }^{27}$, in this case, the reporter stationed in Myanmar found human rights violations against Rohingya ethnicity in vital aspects of life. There were systematic killings against the Rohingya ethnic group in the 2012-2017 quarter. In the "clearance operation" in 2017, there were killings, expulsion, and arson that occurred in hundreds of villages in Maungdaw, Buthidaung, and Rathedaung Cities. ${ }^{28}$ The attacks were carried out brutally and viciously by shooting, slitting, and stabbing any Rohingya they encountered.

Apart from that, sexual crimes against Rohingya women and children also occurred during the "clearance operation" period. The eyewitnesses interviewed by the UN Special Rapporteur are victims of rape who are still alive from the horrific incident. He said that many brutal rapes happened to women aged 13-25 years regardless of

${ }^{23}$ Mohajan, H. (2018). History of Rakhine State and the Origin of the Rohingya Muslims. The Indonesian Journal of Southeast Asian Studies, 2(1), p.13

${ }^{24}$ Saifullah. Op.Cit., p.3

${ }^{25}$ Haradhan. Op.Cit., p.12

${ }^{26}$ Kurniawan, N. (2017). Kasus Rohingya dan Tanggung Jawab Negara dalam Penegakan Hak Asasi Manusia. Jurnal Konstitusi. 14(4), p.881

${ }^{27}$ Gunawan, Y, et al. (2020). Does the Protection of Minority Groups in Xinjiang Fail? Sriwijaya Law Review, 4(2). [Accessed on January 18, 2020] available at http://journal.fh.unsri.ac.id/index.php/sriwijayalawreview/article/view/571/pdf

28 Human Rights Council. (2018). Report of the detailed findings of the Independent International Fact-Finding Mission on Myanmar. [Accessed on January 29, 2020]. Available at https://www.ohchr.org/Documents/HRBodies/HRCouncil/FFMMyanmar/A_HRC_39_CRP.2.pdf, p.78 
pregnancy status. ${ }^{29}$ Religious sentiment also exacerbated the persecution of the Rohingya. Even a prominent monk Ashin Wirathu lectured his followers that Rohingya Muslims are a dangerous ethnicity, resulting in the burning of at least 60 mosques in Rakhine in 2013.30 The impact of the non-recognition of Rohingya citizenship by the Myanmar government is not only affecting the fulfillment of their basic rights but also affects the Rohingya ethnic group not being accommodated to channel their political rights.

\subsection{ASEAN Effort in Settlement Towards Human Rights Violation on Rohingya Ethnic}

ASEAN efforts to form an institution to accommodate regional human rights issues began in 1993 when the ASEAN Ministerial Meeting (AMM) approved the initiation of a regional human rights mechanism in ASEAN. As a realization, in 1998, ASEAN established an informal non-governmental working group of human rights. Along with its development, this institution received less attention from several ASEAN member countries. Until finally, the ASEAN Charter was born, which mandated ASEAN to form a Human Rights Body (Article 14 of the ASEAN Charter). In 2009 the ASEAN Intergovernmental Commission on Human Rights (AICHR) was established for the first time. ${ }^{31}$

The legal basis for the entire operation of AICHR is regulated in full in the AICHR Terms of References (ToR). The function of the establishment of this institution or commission is contained in Article 4 of the AICHR ToR. In Article 4 of the AICHR ToR, there are 14 mandates and functions of the AICHR, all of which rely on promotion and socialization mechanisms.

In terms of institutional structure, AICHR is considered to be less robust because AICHR does not have its own complaint and judicial mechanisms. AICHR is also considered weak because in decision-making, AICHR prioritizes consensus through the implementation of routine meetings twice a year and, if needed, can hold additional meetings if all AICHR representatives from each member country agree to it. 32

Besides the weakness of institutional anatomy, AICHR is also constrained by the principle of non-intervention. Rigidity in the application of the Non-Intervention Principle plays a major role in the ineffectiveness of AICHR in carrying out its duties. It has been proven to have failed in resolving human rights violations against children in the case of "Child Soldiers" who were recruited under the age of 18 to serve as military personnel and were trained as spies, couriers, vanguard soldiers, mine markers, even

${ }^{29}$ Human Rights Council. (2018). Report of the independent international fact-finding mission on Myanmar. [Accessed on January 30, 2020]. Available at https://www.ohchr.org/Documents/HRBodies/HRCouncil/FFM-

Myanmar/A_HRC_39_64.pdf, p.9

30 Journeyman. (2013). The Buddhist Massacring Muslims in Burma. [Accessed on February 1, 2020]. Available at https:/ / www.youtube.com/watch?v=KRzoY-dLc 4\&t=625s

31 Rachminawati \& Mokhtar, K.A. (2019). Protection of Human Rights in Southeast Asia with Special Reference to the Rohingya in Myanmar: A Critical Study of the Effect of ASEAN's Policy and Action on ASEAN Intergovernmental Commission on Human Rights (AICHR). Padjadjaran Journal of International Law, 3(1), p.28-29

32 Saputra, O.B. (2019). Peran ASEAN Intergovernmental Commission on Human Rights sebagai Institusi HAM ASEAN: Kasus Rohingya di Myanmar 2012-2016. Journal of International Relations, 5(1), p.950 
as a sexual outlet. Child soldiers are a human rights violation against children's rights in Myanmar in 2010-2015. In this regard, there have been several reports submitted to AICHR from several NGOs for human rights and children. ${ }^{33}$

In the case of Rohingya's issue, AICHR as an ASEAN regional diplomacy institution, has made efforts in the first meeting of AICHR in Jakarta in 2013 ago. At the meeting, AICHR held a two-hour retreat to discuss the Rohingya case. However, no resolution was reached after the retreat policy. The reason is a consensus system where AICHR cannot make a decision without the consent of all ASEAN member countries. Meanwhile, at that time, Myanmar refused and did not recognize the results of the retreat. Myanmar argued that the Rohingya issue was an internal affair in its own country and would violate the sovereignty of the Myanmar state and violate the principle of non-intervention if the discussion continued. ${ }^{34}$ Meanwhile, at the second meeting on 8-11 February 2014 in Yangon, entitled the plan for the preparation of The AICHR's Recommendation, there was no longer any discussion about the Rohingya case. ${ }^{35}$

3.5. Alternative Ideas for Non-Intervention Principles of ASEAN as Settlement Towards Human Rights Violations on Rohingya Ethnic

The situation of the humanitarian crisis facing the Rohingya ethnic group is increasingly concerning. What Myanmar has been doing to the Rohingya ethnicity has, in fact, led Myanmar to repugnant genocide cases. Jawahir Thontowi, ${ }^{36}$ in an interview with the author, said that what happened to the Rohingya was a crime of genocide. Criminal acts in the form of physically attacking Rohingya ethnics did not happen just once or twice. The pattern was the same and carried out systemically. A large-scale wave of refugees also reinforces the argument of genocide.

The crime of genocide itself is regulated in the Convention on the Prevention and Punishment of the Crime of Genocide 1951 or the Genocide Convention, which recognizes that genocide is an international crime. Against this convention, all countries are considered to have ratified it. As for countries that have not or do not want to ratify, they are still considered to have ratified because they are bound by general legal principles accepted as norms of international law or jus cogens. ${ }^{37}$

Article 2 of the Convention on the Prevention and Punishment of the Crime of Genocide explains the classification of crimes of genocide, such as:

1. Killing members of the group;

33 Amasti, A.Y.N. (2016). Kelemahan Respon ASEAN Intergovernmental Comission on Human Rights (AICHR) terhadap Kasus Tentara Anak di Myanmar 2010-2015. Journal of International Relations, 2(3), p.202

34 Gamez, K.R. (2017). Examining the Asean Intergovernmental Commission on Human Rights (AICHR): The Case Study of The Rohingya Crisis. (Dissertation). Tilburg University. The Netherlands, p.60

${ }^{35}$ Bagus, O. Op.Cit., p.951

36 Interview with Jawahir Thontowi. Professor at the Faculty of Law, Universitas Islam Indonesia on February 6, 2020

37 Dussich, J.P.J. (2018). The Ongoing Genocidal Crisis of the Rohingya Minority in Myanmar. Journal of Victimology and Victim Justice, 1(1), p.13 
2. Causing serious bodily or mental harm to members of the group;

3. Deliberately inflicting on the group conditions of life calculated to bring about its physical destruction in whole or in part;

4. Imposing measures intended to prevent births within the group;

5. Forcibly transferring children of the group to another group.

Several decades later, in 1998, the Rome Statute was formed, which became a breath of fresh air for upholding international human rights. The Rome Statute is a guideline in examining issues regarding the enforcement of justice in tackling international crimes, in this case, especially the crimes of Genocide. Together with that, an independent judicial institution named the International Criminal Court (hereinafter referred to as ICC) was born. ${ }^{38}$ The ICC's jurisdiction under Article 5 of the Rome Statute covers the most serious crimes involving the international community, such as:

1. Genocide;

2. Crimes against humanity;

3. War crimes;

4. Aggression.

Meanwhile, in the regulation regarding genocide, this Statute can be found in Article 6, which forms and classifications of genocide crimes are exactly the same as those in the Genocide Convention.

Various acts of human rights violations against the Rohingya ethnicity that have occurred in Myanmar, as described in detail in the previous discussion, such as the Rohingya people who are not recognized as citizens, restrictions on political rights, murder and persecution, sexual violence against women and children, and destruction of places of worship (mosques), at least it has met the criteria as the most severe crime or extraordinary international crime. Human rights violations against the Rohingya ethnic group are classified as crimes of genocide, as stated in Article 2 of the 1951 Genocide Convention in conjunction with Article 6 of the 1998 Rome Statute.

Furthermore, Myanmar, in its membership of the United Nations since 1950, has played a very minimal role in ratifying conventions that fight for the protection of human rights. For example, the following conventions were not ratified by Myanmar: International Covenant on Civil and Political Rights (ICCPR), International Convention on the Elimination of All Forms of Racial Discrimination (CERD), Convention against Torture and Other Cruel Inhuman or Degrading Treatment or Punishment (CAT), dan Convention for the Protection of All Persons from Enforced Disappearance (CED). ${ }^{39}$ All of the above points show that politically Myanmar's Law does not accede to conventions with the spirit of upholding human rights in order to avoid all forms of legal mechanisms to resolve cases of human rights violations and even genocide that befell the Rohingya ethnicity.

\footnotetext{
38 Wahyuni. (2016). Kejahatan Genosida terhadap Etnis Rohingnya dalam Perspektif Humaniter dan Pertanggungjawaban berdasarkan Statuta Roma (ICC). JOM Fakultas Hukum UNRI, 3(2), p. 3

39 OHCHR. (2019). UN Treaty Body Database. [Accessed on January 5, 2020]. Available at https://tbinternet.ohchr.org/
} 
In the end, the international community cannot expect much from the internal settlement of the Myanmar state, so ASEAN should take a role by removing the circular principle of non-intervention in ASEAN as an effort to resolve human rights violations against the Rohingya ethnicity. This principle is applied rigidly without exception and also easy to be misused as a shield for states that violate human rights against various conflict resolution efforts. But in reality, the juridical basis in the form of the complexity of legal instrumentation in ASEAN, which contains the principle of non-intervention, is not insignificant. Socio-historical facts that are deeply rooted among ASEAN member countries also confirm the existence of the principle of nonintervention because ASEAN prefers to live in maintaining social harmony without interference from other countries, even though it is from fellow ASEAN member countries. Therefore, it will be difficult to "modify" this principle, even though the Rohingya ethnic situation worsens.

There are at least two alternative methods that can be applied in an effort to resolve human rights violations against the Rohingya ethnicity in Myanmar. The two methods are Humanitarian Assistance and Humanitarian Intervention. Both methods are based on human values or "in the name of humanity" so that they can make the principle of non-intervention ineffective.

\subsubsection{Humanitarian Assistance}

The concept of humanitarian assistance is assistance that focuses on humanitarian aspects whose subjects are victims of human rights violations. This concept of humanitarian assistance inherits the teachings of ta' awun or mutual assistance in Islam. History records that humanitarian assistance was once practiced by the people of Medina (the Ansar) in helping by providing asylum, fulfilling basic needs, and giving decent work to people who migrated/changed their place of residence (the Muhajirin) who had their human rights repressed in the land of their birth by the Quraish tribe of Makkah. Humanitarian aid is also a Sunnah which is emphasized by Rasulullah S.A.W through his saying, "You see the believers as regards their being merciful among themselves and showing love among themselves and being kind, resembling one body, so that, if any part of the body is not well then the whole body shares the sleeplessness (insomnia) and fever with it." (Sahih al-Bukhari)

In theory and practice, humanitarian aid does not reduce a country's sovereignty at all. Humanitarian assistance carries four principles. First, humanity prioritizing saving human life and seeks to alleviate suffering. Second, Impartiality, to help without discrimination. Third, neutrality, humanitarian assistance must be free from the influence of any party and not take sides with certain hostilities. Fourth, Independence, humanitarian action has its own autonomy to achieve humanitarian goals. 40

Jawahir Thontowi said that humanitarian assistance or Humanitarian Assistance is considered compatible with ASEAN cultural traditions, which are peaceful, maintain harmony, and stay away from military approaches. Humanitarian aid also serves as a catalyst to initiate a peaceful process through negotiation, mediation, or conciliation between the state and citizens, in this case, the Rohingya ethnic group in Myanmar. Simply put, while helping victims while carrying out peaceful settlement efforts. ${ }^{41}$

\footnotetext{
40 Afriani, A. (2016). Isu Bencana dan Prinsip-Prinsip Humanitarian dalam Studi Ilmu Hubungan Internasional. Andalas Journal of International Studies. 5(1), p.23-26

41 Interview with Jawahir Thontowi, Op.Cit.
} 
ASEAN also took part in Humanitarian Assistance in the Rohingya case through an internal organization called the ASEAN Coordinating Center for Humanitarian Assistance on Disaster Management (AHA Center). The AHA Center aims to facilitate disaster recovery, both natural and humanitarian disasters. Starting operations in 2017 in Rakhine, the AHA Center initiated conciliation and facilitation measures between warring parties. Apart from that, they also provided physical assistance in the form of daily supplies to Rohingya residents who were in exile. The AHA Center's move was well received by the Minister of Social Welfare of Myanmar, Win Myat Aye. 42

Another example is taken from the action carried by Muhammadiyah Disaster Center Management (MDMC). This institution has successfully entered Myanmar to channel aid directly to the Rohingya ethnicity. MDMC, together with Pos Keadilan Peduli Ummat (PKPU), Lembaga Penanggulangan Bencana dan Perubahan Iklim Nahdlatul Ulama (LPBINU), Rumah Zakat, and Dompet Dhuafa, brought three programs to Myanmar as humanitarian assistance: emergency, recovery, and reconciliation. At the emergency stage, the Muhammadiyah Aid team provided assistance in the form of medicines, as well as clothing and food needs. For the recovery program, the Muhammadiyah Aid team distributed assistance in the form of improving education levels, medical and health services. Meanwhile, in the reconciliation program, the Muhammadiyah Aid team built a peace market as a reconciliation effort to stimulate the recovery of Rohingya refugees through organic negotiation interactions between Buddhist Rakhine tribes and Rohingya Muslims. ${ }^{43}$

Humanitarian assistance missions by MDMC and the team in their reconciliation efforts can theoretically be classified into the concept of Facilitative Mediation. According to Margaret Drews,44 "Facilitative mediation is where the parties are encouraged to negotiate based upon their needs and interests instead of their strict legal rights." In other words, Facilitative Mediation encourages the parties concerned (Rakhine Buddhist and Rohingya Muslims) to carry out negotiations based on their needs and interests. The peace market is the implementation of effective Facilitative Mediation for the Rohingya. So that from this market process, it is hoped that it can regain social cohesion that has been strained due to prolonged conflict.

\subsubsection{Humanitarian Intervention}

Humanitarian Intervention is a radical step as a last resort. There is no consensus on the standard definition of Humanitarian Intervention, but Victor Konde provides a simple understanding that humanitarian intervention is a doctrine of international law that was first coined in the 18th century, that humanitarian intervention is a legally legal act for a country to use its military force in the region of another country that carries out brutal and widespread persecution of its own citizens. The purpose of using the military in the territory of another country is to stop the persecution and brutality. ${ }^{45}$

\footnotetext{
42 Rum, M. (2020). The State of Responsibility to Protect Inception in ASEAN Regionalism. The Indonesian Journal of Southeast Asian Studies. 3(1), p.150

43 Khoir. (2012). Pelepasan Tim Kemanusiaan Dompet Dhuafa ke Rohingya. [Accessed on February, 10, 2020]. Available at http://dompetdhuafa.org/id/berita/detail/pelepasan-timkemanusiaan-dompet-dhuafa-ke-rohingya

${ }^{44}$ Drews, M. (2008). The Four Models Mediation. DIAC Journal, 3(1), p.44

45 Victor Konde. (2010). A Handbook of International Human Right Terminology. Nebraska: University of Nebraska Press. p.203
} 
It should be emphasized that this model of humanitarian intervention (military) does not intend altogether to remove the existence of a country's sovereignty but focuses and aims to stop brutal acts and save human rights victims.

Humanitarian intervention arrangements are not detailed in the international legal instruments but can be seen in Chapter VII of the UN Charter. Article 42 mandates the Security Council to be able to take action using the force of the air, sea, and land forces if blockade efforts and embargoes against security disturbing countries are insufficient. The reaffirmation of the use of military intervention is contained in Article 45, which states, the UN allows to carry out of urgent military actions. The sound of Article 45 is coherent with Article 50 and Article 51, which contain the central authority of the Security Council in resolving conflicts and threats. ${ }^{46}$

Humanitarian Intervention had occurred in the Yugoslavia case in 1998, where North Atlantic Treaty Organization (NATO) as a North Atlantic defense force intervened in Yugoslavia because the country under the leadership of Slobodan Milosevic committed human rights crimes against Kosovar civilians who were considered to be an obstacle to Yugoslavia's regional integration program. NATO at that time took unilateral steps to carry out a 78-day offensive (March 24, 1999-June 10, 1999) on the territory of Yugoslavia. Due to the many criticisms of NATO for its authority in conducting the military intervention, NATO finally conducted a series of negotiations which resulted in the NATO mission being endorsed by the UN Security Council with resolution No. 1244.47

It must be admitted that it is possible to misuse this humanitarian intervention for political purposes. Therefore, some international legal experts argue that humanitarian intervention is carried out with several requirements: 48

1. Humanitarian intervention is based on clear reasons and objectives, to protect the human rights of citizens who are victims;

2. It must be done on a proportional and non-excessive basis;

3. Based on clear rules to avoid the possibility of exploitation by a country against the intervened territory.

Bruno Simma added that the use of force for humanitarian purposes must obtain authorization from the UN Security Council so that its legitimacy is clear and in accordance with the purposes of the UN Charter. 49

In the case of Rohingya, ASEAN can play its role as a regional stability and security organization. ASEAN can make NATO a comprehensive reference for humanitarian intervention in Yugoslavia in the late 1990s, where the intervention finally received a "blessing" from the United Nations through UN Security Council Resolution No. 1244 to continue its humanitarian intervention in Yugoslavia. So that humanitarian

\footnotetext{
46 Rattan, J. (2019). Changing Dimensions of Intervention Under International Law: A Critical Analysis. Sage Journal. 9(2), p.3

47 Fitria. (2012). Implementasi Doktrin Responsibility to Protect (Humanitarian Intervention) dalam Hukum Internasional (Kasus Kosovo Libya Dan Suriah). Lex Jurnalica. 9(1), p. 45-46

48 Idris dalam Emi Eliza dkk. (2014). Intervensi Kemanusiaan (Humanitarian Intervention) menurut Hukum Internasional dan Implementasinya dalam Konflik Bersenjata. Fiat Justisia Jurnal Ilmu Hukum, 8(4), p.636

49 Mauna, B. (2005). Hukum Internasional: Pengertian, Peranan dan Fungsi dalam Era Dinamika Global. Bandung: Alumni, p. 650
} 
intervention on behalf of ASEAN is expected to be pushed to the Myanmar government as soon as possible because the intervention already has a strong juridical foundation and real empirical facts. Then the next step is to hold negotiations to get authentic humanitarian intervention together with the UN Security Council as the authority in charge of conducting humanitarian interventions based on the UN Charter.

\section{Conclusions}

Rohingya Muslims Ethnic has been experiencing human rights violations from all vital aspects of life, which are systematically perpetrated by Rakhine people, religious leaders, and elements of the Myanmar state apparatus. The application of the NonIntervention Principles in ASEAN, which is applied rigidly, causes distraction to resolve human rights violations in Myanmar. Thus, the urgency of eliminating the nonintervention principle is a step that should be discussed as a solution to these human rights violations. However, the complexity of ASEAN legal instruments and documents containing the non-intervention principles, as well as the similarity to socio-historical factors, makes it difficult to abolish the existence of ASEAN's nonintervention principle. There are at least two methods that can be applied as an alternative effort to resolve human rights violations against the Rohingya ethnic group. Both are based on humanitarian values, which can make the non-intervention principle work ineffective. The first methods are Humanitarian Assistance which focuses on victims, in this case, the Rohingyas group. The second methods are Humanitarian Intervention as a last resort using a collective military approached directed to the Myanmar government.

\section{References}

\section{Books}

Mauna, B. (2005). Hukum Internasional: Pengertian, Peranan dan Fungsi dalam Era Dinamika Global. Bandung: Alumni.

Weatherbee, D.E. (2009). International Relation in Southeast Asia: The Struggle for Autonomy. USA: Rowman \& Littlefield Publishing Group.

Burmansyah, E. (2014). Rezim Baru ASEAN: Memahami Rantai Pasokan dan Masyarakat Ekonomi ASEAN. Yogyakarta: Pustaka Sempu.

Adolf, H. (1996). Aspek-Aspek Negara dalam Hukum Internasional. Jakarta: Raja Grafindo Persada.

Ibnu Taimiyah, Al-Siyasah al-Syari'ah

Irawan, J. (2018). Pelaksanaan Yurisdiksi Universal. Yogyakarta: Rajawali Press.

Islami, M.N. (2017). Hukum Internasional dalam Perspektif Islam dan Kedaulatan Bangsa. Yogyakarta: Pustaka Pelajar.

Kusumaatmadja, M \& Agoes, E.R. (2003). Pengantar Hukum Internasional, Bandung: Penerbit Alumni.

Saifullah. (2010). Sejarah dan Kebudayaan Islam di Asia Tenggara. Yogyakarta: Penerbit Pustaka Pelajar. 
Konde, V. (2010). A Handbook of International Human Right Terminology. Nebraska: University of Nebraska Press.

\section{Journals}

Afriani, A. (2016). Isu Bencana dan Prinsip-Prinsip Humanitarian dalam Studi Ilmu Hubungan Internasional. Andalas Journal of International Studies. 5(1).

Amasti, A.Y.N. (2016). Kelemahan Respon Asean Intergovernmental Comission on Human Rights (AICHR) terhadap Kasus Tentara Anak di Myanmar 2010-2015. Journal of International Relations, 2(3).

Djauhari. (2005). Kedaulatan Rakyat dalam Perspektif Islam. Jurnal Hukum, 15(2).

Eliza, E. et al. (2014). Intervensi Kemanusiaan (Humanitarian Intervention) menurut Hukum Internasional dan Implementasinya dalam Konflik Bersenjata. Fiat Justisia Jurnal Ilmu Hukum, 8(4).

Fitria. (2012). Implementasi Doktrin Responsibility to Protect (Humanitarian Intervention) dalam Hukum Internasional (Kasus Kosovo Libya Dan Suriah). Lex Jurnalica. 9(1).

Gunawan, Y. \& Priambodo, G. (2013). Burma's Rohingya Case in International Law Perspective. Jurnal Media Hukum, 20(1).

Mohajan, H. (2018). The Rohingya Muslims in Myanmar are Victim of Genocide. ABC Journal of Advanced Research, 7(1).

Mohajan, H. (2018). History of Rakhine State and the Origin of the Rohingya Muslims. The Indonesian Journal of Southeast Asian Studies, 2(1).

Thamrin, H. (2018). Rohingya-Myanmar Crisis: How Is ASEAN Intergovernmental Commission on Human Rights?. International Affairs and Global Strategy, 63(1).

Jati, I. (2017). Comparative Study of the Roles of ASEAN and the Organization of Islamic Cociteration in Responding to the Rohingya Crisis, The Indonesian Journal of Southeast Asian Studies. 1(1).

Dussich, J.P.J. (2018). The Ongoing Genocidal Crisis of the Rohingya Minority in Myanmar. Journal of Victimology and Victim Justice, 1(1).

Rattan, J. (2019). Changing Dimensions of Intervention Under International Law: A Critical Analysis. Sage Journal. 9(2)

Linjun, W.U. (2000). East Asia and the Principle of Non-Intervention: Policies and Practices. Maryland Series in Contemporary Asian Studies, 5(160).

Drews, M. (2008). The Four Models Mediation. DIAC Journal, 3(1).

Rum, M. (2020). The State of Responsibility to Protect Inception in ASEAN Regionalism. The Indonesian Journal of Southeast Asian Studies. 3(1).

Kurniawan, N. (2017). Kasus Rohingya dan Tanggung Jawab Negara dalam Penegakan Hak Asasi Manusia. Jurnal Konstitusi. 14(4).

Saputra, O.D. (2019). Peran Asean Intergovernmental Commission on Human Rights Sebagai Institusi HAM Asean: Kasus Rohingya di Myanmar 2012-2016. Journal of International Relations, 5(1). 
Rachminawati \& Mokhtar, K.A. (2019). Protection of Human Rights in Southeast Asia with Special Reference to the Rohingya in Myanmar: A Critical Study of the Effect of ASEAN's Policy and Action on ASEAN Intergovernmental Commission on Human Rights (AICHR). Padjadjaran Journal of International Law, 3(1).

Rahmanto, T.Y. (2017). Prinsip Non-Intervensi bagi Asean ditinjau dari Perspektif Hak Asasi Manusia. Jurnal HAM, 8(2).

Wahyuni. (2016). Kejahatan Genosida terhadap Etnis Rohingnya dalam Perspektif Humaniter dan Pertanggungjawaban berdasarkan Statuta Roma (ICC). JOM Fakultas Hukum UNRI, 3(2).

Gunawan, Y., Ritonga, P.Y., Amelia, M., Harun, S.S.K., \& Ramadani, N.N. (2020). Does the Protection of Minority Groups in Xinjiang Fail? Sriwijaya Law Review, 4(2).

Thesis

Amora, M. (2010). Arti Strategis Piagam Asean (Asean Charter) terhadap Kerjasama Regional Asean. (Tesis). Universitas Indonesia, Indonesia.

\section{Dissertation}

Gamez, K.R. (2017). Examining the Asean Intergovernmental Commission on Human Rights (AICHR): The Case Study of the Rohingya Crisis. (Dissertation). Tilburg University. The Netherlands.

\section{Internet Articles}

Human Rights Council. (2018). Report of the Detailed Findings of the Independent International Fact-Finding Mission on Myanmar. [Accessed on January 29, 2020]. Available at, https://www.ohchr.org/Documents/HRBodies/HRCouncil/FFMMyanmar/A_HRC_39_CRP.2.pdf

Human Rights Council. (2018). Report of the independent international fact-finding mission on Myanmar. [Accessed on January 30, 2020]. Available at, https://www.ohchr.org/Documents/HRBodies/HRCouncil/FFMMyanmar/A_HRC_39_64.pdf

Journeyman. (2013). The Buddhist Massacring Muslims in Burma. [Accessed on February 1, 2020]. Available at, https://www.youtube.com/watch?v=KRzoY$\underline{\mathrm{dLC} \_4 \& \mathrm{t}=625 \mathrm{~s}}$

Khoir. (2012). Pelepasan Tim Kemanusiaan Dompet Dhuafa ke Rohingya. [Accessed on February 10, 2020]. Available at, http://dompetdhuafa.org/id/berita/detail/pelepasan-tim-kemanusiaandompet-dhuafa-ke-rohingya

OHCHR. (2020). UN Treaty Body Database. [Accessed on January 5, 2020]. Available at, https://tbinternet.ohchr.org/

Salim, T. (2016). No ASEAN Meeting to Discuss Rohingya. [Accessed on March 27, 2021]. Available at, https://www.thejakartapost.com/news/2016/11/26/noasean-meeting-to-discuss-rohingya.html 